University of Warwick institutional repository

This paper is made available online in accordance with

publisher policies. Please scroll down to view the document

itself. Please refer to the repository record for this item and our

policy information available from the repository home page for further information.

To see the final version of this paper please visit the publisher's website. Access to the published version may require a subscription.

Authors: $\quad$ Steve Strand

Article title: The limits of social class in explaining ethnic gaps in educational attainment

Year of 2009

publication:

Link to http://www.tandf.co.uk/journals/carfax/01411926.html

published

version:

Publisher None

statement: 
The limits of social class in explaining ethnic gaps in educational attainment

Paper accepted for publication in the British Educational Research Journal. Please cite as Strand. S. (in press). The limits of social class in explaining ethnic gaps in educational attainment. British Educational Research Journal, in press.

Accepted for publication 4/12/2009. Estimated date of publication: 18 months.

\author{
Dr Steve Strand \\ Associate Professor \\ Institute of Education \\ University of Warwick \\ England, UK
}

Tel: 0442476522197

e-mail: steve.strand@warwick.ac.uk

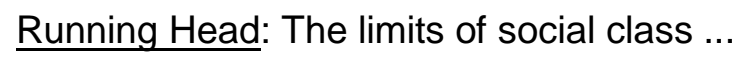

Keywords: ethnicity, gender, social class, equity, attainment, progress 


\section{The limits of social class in explaining ethnic gaps in educational attainment}

\section{ABSTRACT}

This paper reports an analysis of the educational attainment and progress between age 11 and age 14 of over 14,500 students from the nationally representative Longitudinal Study of Young People in England (LSYPE). The mean attainment gap in national tests at age 14 between White British and several ethnic minority groups were large, more than three times the size of the gender gap, but at the same time only about one-third of the size of the social class gap. Socio-economic variables could account for the attainment gaps for Black African, Pakistani and Bangladeshi students, but not for Black Caribbean students. Further controls for parental and student attitudes, expectations and behaviours indicated minority ethnic groups were on average more advantaged on these measures than White British students, but this was not reflected proportionately in their levels of attainment. Black Caribbean students were distinctive as the only group making less progress than White British students between age 11 and 14 and this could not be accounted for by any of the measured contextual variables. Possible explanations for the White British-Black Caribbean gap are considered.

\section{INTRODUCTION}

Public concern about the attainment of ethnic minority groups has been long standing both in the UK and US. The seminal work of the Coleman report (1966) was the first to report a comprehensive collection of nationally representative data across the US. Verbal and nonverbal reasoning, reading and mathematics tests were completed at age 8,11, 14 and 17. The results revealed a consistent picture where "the black student averages tend to be about one standard deviation below those of whites" (p219). Early work in the UK was summarised in the Swann report (1985) which concluded that Black Caribbean children "as a group are underachieving in our education system". While ethnic gaps may have decreased somewhat in more recent data (e.g., Hedges \& Nowell, 1998; Fryer \& Levitt, 2004) they still persist. The most recent data from the US National Assessment of Educational Progress (NAEP) 2005 indicate that in reading at age 9 years $41 \%$ of White students scored at or above proficient compared to $13 \%$ of their Black peers, with a similar ethnic gap in mathematics ( $47 \%$ and $13 \%$ respectively). Similarly large gaps were also apparent at age 14 and age 18 (see KewalRamani et al., 2007). A recent topic paper on ethnicity and education from the Department for Education and Skills in England (DfES, 2006) reviewed national test data at age 7, age 11 and age 14 and public examinations at age 16 . The data also reveal substantial attainment gaps between ethnic groups in contemporary data. Broadly speaking, the mean scores of Black Caribbean, Black 
African, Black Other, Pakistani and Bangladeshi students are below the mean for their White British peers, while the mean scores for Chinese, Indian and Irish students are higher than the mean of their White British peers.

The most frequently cited explanation for ethnic gaps in educational attainment relates to the substantial differences in socio-economic status between Black and White groups. For example the US Census reports $8 \%$ of Whites living in poverty compared to $11 \%$ of Asians, $22 \%$ of Hispanics and $25 \%$ of both Blacks and Native Americans (US Census Bureau, 2006). In England the Labour Force Survey 2004/05 defines 20\% of White British households as being in income poverty compared to $25 \%$ of Indian, $30 \%$ of Black Caribbean, $45 \%$ of Black African, $55 \%$ of Pakistani and $65 \%$ of Bangladeshi households (Kenway \& Palmer, 2007).

Socioeconomic disadvantage may have a direct influence on children's development, for example through limited material resources and an increased risk of a range of health and developmental problems, and an indirect influence through parental education, expectations and aspirations (e.g., McLoyd, 1998).

However large scale representative studies have had mixed success in eliminating the attainment gap using controls for socio-economic status. Phillips, Brooks-Gunn, Duncan, Klebanov and Crane (1998) in an extensive analysis of the survey of the Children of the National Longitudinal Study of Youth (CNLSY) report traditional socio-economic measures account for no more than one-third of the Black-White test score gap at age 5/6 years. Further controls for a broader range of family environment and parenting practices were more successful, accounted for two-thirds of the Black-White attainment gap. Similarly Fryer \& Levitt (2004) in a recent study with 20,000 US children born in the mid 1990's and surveyed through the Early Childhood Longitudinal Study-Kindergarten (ECLS-K) reports that controls for SES (parental occupation, education and income) reduced the Black-White gap in attainment on entry to Kindergarten by $40 \%$ in mathematics and by two-thirds in reading. Further controls (including number of books in the home, sex, mothers age and birth weight), were able to reduce the gap in maths to -.09 SD and eliminated the gap in reading. In the UK, Strand (1999) analysed the results for over 5,000 pupils aged 4 in inner London and reports that the Black Caribbean-White British attainment gap was -0.26 SD and was not eliminated by controls for poverty, age, sex, special educational needs, fluency in English or number of terms of preschool education. Studies with older students generally report that controls for socio-economic status reduce the Black-White attainment gap by no more than one-third and often by less, and that substantial gaps remain. For example Hedges and Nowell (1998) report that in the National Educational Longitudinal Study the Black-White gap at age 18 only reduced from -0.82 SD to 0.65 SD after control for parental education and income. In the UK, Demack, Drew \& Grimsall 
(2000) using the Youth Cohort Study report that at age 16 ethnic gaps still persist even when gender and social class were taken into account. Wilson, Burgess \& Briggs (2005) analyse national data on examination results at age 16 and report that Black Caribbean pupils still had lower attainment than White British students after control for age, poverty, gender, special educational needs and neighbourhood deprivation (although the difference was less than -0.10 SD). However as with younger students factors other than SES, such as parental involvement and educational aspirations, may account for more of the gap (e.g., Yan \& Lin, 2005, Strand \& Winston, 2008).

National population data are powerful in establishing the existence of ethnic gaps in educational attainment. However population data typically contain very limited contextual data to help interpret these results, breadth comes at the price of depth. Research is needed using longitudinal datasets that combine the benefits of nationally representative samples with detailed and rich data on possible explanatory factors. This is particularly the case in England where there has been no longitudinal study covering educational attainment in adolescence since the Birth Cohort Study of 1970. The Longitudinal Study of Young People in England (LSYPE) offers the opportunity to explore these issues with a recent and large nationally representative sample. The LSYPE interviewed a representative sample of over 15,000 young people aged 14 years in 2004. It also interviewed their parents/guardians and collected a wide range of quantitative data about the students, their families and their school and neighbourhood contexts. The primary aim of this paper is to focus on the relationships between various student, family, school and neighbourhood factors and educational attainment and progress in the first three years of secondary school (age 11 to age 14), with a particular focus on understanding the reasons for differences in the educational attainment and progress of different ethnic groups. The following specific research questions are posed:

- What are the size of ethnic gaps in educational attainment at age 14 , and in educational progress between age 11 and age 14?

- What other student, family, school and neighbourhood factors are significantly associated with attainment and progress?

- Can these factors account for (statistically explain) differences in the educational attainment and progress of different ethnic groups? 


\section{METHODOLOGY}

\section{Sample}

The dataset used here is wave 1 of the Longitudinal Study of Young People in England (LSYPE). Wave 1 occurred in summer 2004, and the target population was young people born between $1^{\text {st }}$ September 1989 and $31^{\text {st }}$ August 1990 and attending Year 9 (US Grade 8) in all schools in England. LSYPE used a two stage sampling procedure. At the first stage a sample of schools was drawn with probability proportionate to size from a stratified frame by school deprivation status. Deprived schools, defined as those in the top quintile of the percentage of students entitled to free school meals, were over-sampled in the ratio 1.5:1. Schools were also stratified by region and by school admission policy (comprehensive, selective and secondary modern). At the second stage a sample of students in $Y 9$ was drawn from the school rolls along with their parental and address details. Sample boosts took place for ethnicity at the student level with boosts made in the following six groups: Black African; Black Caribbean;

Bangladeshi; Indian; Pakistani and Mixed heritage. The method used delivered both a constant sampling fraction for each sub-population and a fixed cluster size and therefore avoided precision losses through corrective (design) weighting and excessive variation in cluster sizes.

While the total LSYPE sample was 15,770 households, not all cases were eligible for inclusion in this analysis of attainment at age 14. 938 students had no recorded age 14 test scores, including all 530 students drawn from private schools where national tests are optional. Additionally 329 students were not interviewed or refused to give their ethnicity so the eligible sample was 14,503 students drawn from 629 schools with an average number of students per school of 22.7 (range 1 to 45, SD 5.3). In the analyses to follow the data have been weighted to compensate for differential selection chances in the sample design and to remove nonresponse biases. Non response weights were calculated through comparison of respondents to School Census student level population data. The combined design and non-response weights are applied using the SPSS Complex Samples module V15.0. Deprivation status was included as a separate stratum selected with unequal probability (1.5:1) and school (the primary sampling unit) was identified as a cluster variable. The application of these features ensures the calculation of appropriate standard errors and allows for the recapture of population figures. A full description of the procedures used in drawing the sample is contained in Strand (2007). 


\section{Measures}

\section{Educational attainment}

Age 14 average test score: At the end of Year 9 students complete national tests in English, mathematics and science. The actual test marks obtained by each student, and the test tier to which they were entered, were used to generate 'fine grained' test levels on a decimal scale. These fine grained levels were then converted to points scores to give differentiated outcome measures and were combined to create an average points score which was normally distributed with a mean of 33.5 and SD of 6.7 (range 15.0 - 48.8). Each point score corresponds to roughly four months progress in terms of the original conception of a National Curriculum level as representing two years of educational progress (TGAT, 1988). This was the dependent variable in models of educational attainment.

Age 11 average test score: At the end of Year 6 all students in England complete national tests in English, mathematics and science. There are a total of eight tests in reading, writing, spelling, mathematics with and without a calculator, mental mathematics, and two tests in science. The total test marks obtained by each student were summed across all tests and the resulting total was subject to a normal score transformation so the mean age 11 test score is represented by zero with a SD of 1 . Including this variable in regression models along with the pupils' age 14 average test score gave a measure of pupils' educational progress.

\section{Measures derived from LSYPE}

LSYPE data collection was based on separate 45 minute face-to-face interviews with the young person and with their parents, conducted in the respondents own home. A shorter 10 minute interview with the second parent (where present) covered only employment details and employment history. An initial analysis of the LSYPE data created a set of variables that were both (i) significantly associated with educational attainment at age 14, and (ii) varied significantly across different ethnic groups (see Strand, 2007 for detail). The variables are organised into four blocks based on a theoretical model of the nature of various influences on educational attainment (Powdthavee, Levacic \& Vignoles, 2006). The four main blocks were composed of:

- Family background: Structural features such as the social class of the home, maternal education, entitlement to a Free School Meal, home ownership and family composition which, although time variant, are relatively stable of aspects of the home environment. 
- Parental attitudes and behaviour. A set of variables entered before any individual student variables on the presumption that family influences logically precede or at least create the context for individual student attitudes and behaviour.

- Student risk and protective factors: these included both risk factors which were associated with an increased likelihood of low attainment at age 14, and protective factors including attitudes or motivations that were positively associated with high attainment.

- School context and neighbourhood deprivation: These were entered last to determine whether school or neighbourhood deprivation had any effect over and above the influence of individual and family factors.

The division of variables between these blocks is not a rigid demarcation but is a useful way of structuring the wide range of data available through LSYPE. Twenty-seven specific variables were created and are described in detail in Appendix 1.

\section{Analytical approach}

The data are analysed in a multiple regression framework which identifies the unique (net) contribution of particular variables to variation in educational attainment while other background variables are controlled. This is important because differences in attainment between ethnic groups may be attributable to the impact of socio-economic and demographic factors, as described in the introduction. The analysis adopts a hierarchal approach by sequentially entering the four blocks of variables described above. While there is a substantial body of research establishing the relation between structural variables such as social class and educational attainment (e.g. Sirin, 2005), there is relatively little evidence of the mechanisms or the more proximal influences through which this association is mediated. By entering the structural factors first, it is possible to explore the subsequent effect of entering more dynamic family or individual measures. If these more proximal measures influence or mediate the effect of social class we might expect the inclusion of these variables to both improve the prediction of educational attainment and to reduce the relative impact of socio-economic variables. This may also help to better understand how socio-economic effects on attainment are mediated.

\section{$\underline{\text { Treatment of missing data }}$}

Because of the large number of variables to be employed in the analysis listwise deletion rapidly reduced the sample to around 9,000 cases. To prevent such data loss missing values were explicitly included as dummy categories within each variable. Variables that had initially 
been calculated as continuous scales (such as academic self concept and attitude to school) were divided into discrete categories. This has advantages since it: (i) prevents the loss of explanatory power that would come from listwise deletion;(ii) allows for the direct modelling of missing data rather than imputing values, for example by mean substitution, which has its own interpretative problems; (iii) allows for non-linearities in the relationships with attainment; (iv) can simplify the interpretation of the relationships with attainment, since we can directly contrast different groups; and (v) ensures a consistent base in terms of the sample size across a range of hierarchical regression models including increasingly large number of explanatory variables.

\section{RESULTS}

\section{Comparison of mean scores at age 14}

Analyses were completed separately for each of the English, mathematics and science tests. The results revealed a consistent picture with the mean scores for Pakistani, Bangladeshi, Black Caribbean and Black African groups significantly lower than for White British students in all three subjects. Pakistani students had a particularly low mean score in English, and Black Caribbean students a particularly low mean score in mathematics, relative to all other ethnic groups. However given the consistent pattern across subjects subsequent analyses will focus on age 14 average test score.

Table 1 presents the mean and SE of the average age 14 test score by ethnic group, social class and gender. In relation to ethnic group, the mean score for Indian pupils was slightly higher than for White British students $(p<.05)$ and there was no significant difference between the mean scores for White British, Mixed heritage and Any Other ethnic group. However the mean score for Pakistani, Bangladeshi, Black African and Black Caribbean students were all significantly lower than for White British students by around three points. This is equivalent to over a whole year of progress in terms of the definition of NC levels. Thus ethnic group differences in attainment at age 14 are substantial.

Table 1 allows a comparison of the size of the ethnic, gender and social class gaps. The gender gap was just 0.8 points with boys scoring lower than girls. In comparison the ethnic gap (the difference between White British and Black Caribbean students) was more than three times larger at 3.3 points. The ethnic gap was in turn only around one-third of the social class gap, with a 9.6 point gap between students from higher managerial and professional homes and those where the main parent was long term unemployed. These results are in stark 
contrast to the attention paid to each of these 'gaps' in the UK media, who focus almost exclusively on the gender gap.

$<---$ Insert Table 1 about here ---- >

However ethnicity and social class are themselves correlated, so that at least in part the ethnic gaps may reflect average differences in social class. Appendix 2 presents a breakdown within each ethnic group of the proportion of students at all levels of the explanatory variables described in Appendix 1. This shows for example that (when excluding missing cases) $42 \%$ of White British students are from homes in the top two social classes, compared to $37 \%$ of Black Caribbean, $36 \%$ of Black African, $29 \%$ of Indian, $19 \%$ of Pakistani and only $9 \%$ of Bangladeshi students. At the other end of the scale, the proportion of students from homes where the head of the household has never worked or is long term unemployed is 3\% for White British but $7 \%$ for Indian, 8\% for Black Caribbean, 23\% for Pakistani, 26\% for Black African and $40 \%$ for Bangladeshi households. A fuller description and discussion of this descriptive data is contained in Strand (2007). The next section uses multiple regression analyses to attempt to identify the net influence of ethnicity in relation to attainment.

\section{Contextual analysis of attainment at age 14}

Table 2 presents the results of the multiple regression analyses for age 14 average test score. Model I includes only ethnic group as an explanatory variable and shows the simple association between ethnic group and age 14 test score before taking account of any other variables. The model shows a statistically significant and substantial association between ethnicity and attainment, as already described.

\section{Model II - Family background}

All six family background variables were strongly and significantly related to attainment and overall explained $25 \%$ of the variance in age 14 average score. Looking at the individual coefficients maternal education had the largest association with attainment, a gap of 5.9 points between young people with mothers with a degree or higher vs. mothers with no educational qualifications. The effect of social class was next largest with a gap of 3.8 points between the higher managerial and professional group and the long term unemployed. These effects are additive, so taken together social class and maternal education are associated with a 10 point gap in attainment (equivalent to three years' of progress in NC levels), four times larger than the biggest ethnic gap which was the 2.5 point gap between Black Caribbean and White British students. The gender gap was just 0.7 points. There were also significant negative associations 
with entitlement to FSM (-2.0 points), being in rented rather than owned accommodation (-1.9 points) and being in a single parent family (-0.4 points).

Generally, after taking account of family background, Indian and Bangladeshi students achieve higher results than would be expected given their socio-economic circumstances. For Pakistani students the extent of underachievement relative to White British students is reduced by $80 \%$ from -3.1 to -0.7 points, and for Black African students by $66 \%$ from -3.0 to -1.1 points. What is notable is how small the impact of these controls is on the attainment of Black Caribbean students. The Black Caribbean coefficient has only dropped by $25 \%$ from -3.3 to -2.5 points and is still substantially below the White British mean even after accounting for the social class of the home, gender, maternal education, entitlement to FSM, home ownership and single parent status.

$$
<--- \text { Insert Table } 2 \text { about here ---- > }
$$

\section{Model III: Parental attitudes and behaviours}

This block added six further variables to the model, all of which were positively associated with attainment. Parental expectations that the student would continue in FTE post 16 was associated with higher attainment (4.0 points), as was providing a home computer (2.1 points), a low level of quarrelling with the student (1.7 points), a high level of parental involvement with the school (1.0 point), parental supervision (1.1 points) and providing private tuition (0.5 points). Overall adding these variables provided a modest boost to the explanatory power of the model raising the percentage of the variance explained from $25 \%$ to $34 \%$. These changes tended on the whole to impact negatively on the coefficients for all minority ethnic groups. This is because most groups were more advantaged on these measures than the White British group. On average minority ethnic parents were more likely to have paid for private tuition, more involved with their child's school, had higher educational aspirations for their children, were more likely to know where their children were when they were out and less likely to quarrel with the children (see Appendix 1). All these are generally advantaging factors, as shown by the above coefficients, but they were not associated with proportionately greater attainment within the minority ethnic groups.

\section{Model IV - Student risk and protective factors}

This stage added a further eleven explanatory variables which substantially improved the amount of variance explained from $34 \%$ to $53 \%$. The most substantial influences were SEN associated with a 5.6 point decrement; academic self concept with a 5.0 point difference 
between the top and bottom bands; homework with a 3.0 point gap between those completing homework every evening vs. those never completing homework; planning for the future with 2.3 point gap between the top and bottom bands and student educational aspirations with a 1.6 point boost for those students planning to continue in FTE post 16. There were negative associations of attainment with extended absence from school (-0.8), being excluded $(-0.7)$, involvement with the police (-0.5), truanting (-0.3) and Social Service or EWS contact because of the student's behaviour (-0.3). Interestingly a positive attitude to school was negatively associated with attainment, though it was positively associated with progress age 11-14 (see model VI, Table 2).

Again the net effect of including these variables was (with the exception of Black Caribbean students) to further depress the coefficients for minority ethnic groups relative to White British. The coefficients for Indian, Pakistani, Bangladeshi and Black African groups relative to White British all declined by over 1.0 point relative to Model III. Again this is because most minority ethnic groups were more advantaged on these measures than White British students. On average minority students were more likely to aspire to continue in education post 16 , to have a positive academic self concept, to plan for the future and to have a positive attitude to school, and less likely to have been excluded (except Black Caribbean students) or to have had extended absence (except Pakistani students). All these are advantaging factors across the sample as a whole, as shown by their coefficients, but they were not associated with proportionately greater attainment within the minority ethnic groups.

\section{Model V - School and neighbourhood context}

The last model added four school level variables and the measure of neighbourhood deprivation. These variables accounted for additional amounts of previously unexplained variance, increasing the percentage of variance explained from $53 \%$ to $58 \%$. It is notable that even after the detailed and wide ranging controls at the individual student and family level, there were still substantial associations with school context. This model included no controls for prior attainment, so some of these school factors may reflect differences in the attainment of the intake to different types of schools (see model VI for 'value added' comparisons). Students attending grammar schools scored on average 4.7 points higher, and students in secondary modern schools -1.2 lower, than students attending comprehensive schools; students in the most deprived schools ( $35 \%$ or more entitled to FSM) scored -3.1 points below those in the least deprived schools ( $<5 \%$ entitled to FSM); students in girls schools achieved on average 0.9 points higher than mixed sex schools; and students in Church schools scored 0.4 points higher than students in community schools. Even after these school level variables were included, 
neighbourhood deprivation (IDACI score) has a significant association with attainment with a 0.6 point difference between those living in neighbourhoods one SD above the mean deprivation compared to those living in neighbourhoods one SD below the mean deprivation.

Minority ethnic students were much more likely to attend deprived schools, less likely (except Indian students) to attend grammar schools, more likely to attend single-sex girls schools and lived in substantially more deprived neighbourhoods than White British students. As a result the gaps for Pakistani, Bangladeshi, Black Caribbean and Black African groups relative to White British closed by roughly 1.0 point compared to Model IV, but were still substantial. Looking at the ethnic coefficients, the contextual variables effectively account for the low attainment of the Bangladeshi group. They also explain a substantial part of the low attainment of Pakistani students who still appear to underachieve by -1.5 points, but this is half the -3.0 point difference in unadjusted attainment. However the success of the model in accounting for the low attainment of Black Caribbean and Black African students is much smaller. Even after including all the contextual variables these groups are still achieving around -2.5 points less than would be expected given their family, student, school and neighbourhood context. Indian students are also underachieving since although their unadjusted age 14 score is 0.55 of a point above that of White British students, it is -0.50 of a point below what might be expected given the family, student, school and neighbourhood contexts.

Figure 1 presents a summary of the ethnic coefficients over the five models. Confidence intervals around these means are not shown, but can be inferred from the standard errors given in Table 2.

$$
<--- \text { Insert Figure } 1 \text { about here ---- > }
$$

\section{Educational progress age 11-14}

The models described so far have sought to explain differences in educational attainment at age 14. By adding each student's prior attainment at age 11 the model addresses differences in educational progress age 11-14. This section asks whether there are differences between ethnic groups in progress age 11-14, and if so whether the differences can be explained by the contextual variables available in the LSYPE dataset.

Table 3 presents the mean age 11 average test score for each ethnic group. The results reveal the mean age 11 score for Pakistani students was almost half a SD below the mean for White British students, the means for Black Caribbean and Bangladeshi students were nearly one- 
third of a SD lower and the mean for Black African students was one-quarter of a SD below the mean for White British. Prior attainment is an extremely powerful predictor of later attainment (the correlation between students' age 11 and age 14 average test score is .89) so age 11 average test score can account for $79 \%$ of the variance in age 14 average test score. The last two columns give a measure of progress age 11-14. The substantial ethnic gaps at age 14 for Pakistani, Bangladeshi and Black African students reflect earlier differences already existing at age 11: the gaps relative to White British students neither widen nor lessen during the first three years of secondary school. For these groups it is therefore essential to explore influences occurring during primary school to better understand the nature of the gaps. There are however two ethnic groups where the gaps actually grow during the first three years of secondary school: Indian students make 0.80 points more progress than White British students pulling further ahead than they were at age 11, and Black Caribbean students make 0.77 points less progress than White British students falling further behind than they were at age 11 .

$$
<--- \text { Insert Table } 3 \text { about here ---- > }
$$

To explore whether these difference in educational progress can be explained by the contextual variables, Model VI in Table 2 adds age 11 score to all the other explanatory variables to form a contextual value added model. Because prior attainment accounts for so much of the variance in age 14 score, the coefficients for most explanatory variables are smaller than they were in the model V. However there are still statistically significant associations between the contextual variables and student progress.

Family background: Students from higher managerial and professional homes made more progress (0.4) than students from households where the main parent was long term unemployed, as did students from the small employers/self-employed group (0.3), but none of the other contrasts are significant. Students of mothers educated to degree level made more progress (0.9) than those with mothers with no qualifications, and there were significant but decreasing boosts associated with mothers with higher education but below degree (0.5), ' $A$ ' level or equivalent (0.3), GCSE $5+A^{*}$-C or equivalent $(0.2)$ and with other qualifications $(0.2)$. Students entitled to FSM made less progress $(-0.2)$ than their peers not entitled to FSM.

Parental attitudes and behaviour: High parental educational aspirations (0.7), providing a home computer (0.5), high parental involvement in school (0.4), parental supervision (0.4), a low frequency of quarrelling with children (0.3) and providing private tuition (0.3) also have significant positive associations with student progress. 
Student risk and protective factors: All the variables have a significant association with progress, most notably: students in the top band of academic self-concept make more progress (1.4) than those in the bottom band; students completing any amount of homework make more progress than those completing none, ranging from 1.1 points for those completing homework every weekday evening to 0.3 for those completing homework only one evening a week; Students with identified SEN make less progress $(-1.2)$ than their peers without SEN; students who plan for the future make more progress $(0.7)$ than those who do not plan; students ever excluded from school make less progress $(-0.7)$ than those never excluded; students whose behaviour has led to the involvement of the police make less progress (-0.5); students who aspire to continue in FTE after the age of 16 make more progress (0.5), students who have had long term absence make less progress (-0.4); students who have truanted during the key stage make less progress (-0.3); students whose behaviour has led to social services/EWS involvement make less progress (-0.2), and students in the top band for attitude to school make more progress $(0.1)$ than those in the bottom band.

School and neighbourhood context: students in the most deprived schools make less progress $(-1.4)$ than those in the least deprived schools; students attending grammar schools make more progress (0.4) than students attending comprehensive schools; girls in single sex schools (but not boys in single sex schools) make more progress $(0.5)$ than students in mixed sex schools; and over and above the impact of individual and school disadvantage, students living in more deprived areas make less progress (-0.3) than those living in better off areas (contrast between +/- 1 SD of IDACI score).

With respect to ethnic group, and once all the above contextual factors are included, the better progress of Indian students relative to White British students is somewhat moderated $(0.30$ points) though still highly statistically significant. The poor progress of the Black Caribbean students relative to White British is not explained at all, remaining at around -0.80 points. Black African students also appear to make less than expected progress relative to similar White British students, although the statistical significance of the effect is much lower $(-0.29$ points, $p<.05$ ).

\section{Interactions between ethnic group, gender and social class}

Interactions between ethnic group and gender were explored in additional models, not shown in Table 2. There was no significant interaction between ethnicity and gender in the 'base' model or in any of the contextual models. There were some ethnic by gender interactions for student progress in the contextual value added model indicating that Bangladeshi girls made more progress (0.3) and Bangladeshi boys less progress (-0.3) than expected. Ethnic group by social 
class interactions were also investigated but were relatively weak, and the ethnic gaps were highly significant at all levels of social class.

\section{DISCUSSION}

\section{Contextualising ethnic gaps in educational attainment at age 14}

This research has reported wide variation in educational attainment at age 14 between different ethnic groups. Pakistani, Bangladeshi, Black Caribbean and Black African groups achieve an average age 14 score around 3.0 points below the White British group, equivalent to around a whole year of progress in terms of the TGAT framework (1988). Explanations of these gaps in terms of socio-economic status (social class of the home, maternal education, gender, poverty, home ownership and single parent status) have mixed success in accounting for the gaps. Indian and Bangladeshi students achieve higher results than would be expected given their social class and maternal educational qualifications. The Pakistani gap relative to White British students is reduced by over $80 \%$, and the gap for Black African students is reduced by twothirds. However the low attainment of the Black Caribbean group is not substantially reduced, and their mean KS3 score remains -2.5 points below the comparable White British mean. Socio-economic status therefore does not provide an adequate account of all ethnic group differences in attainment at age 14.

As well as the family background variables, further contextual models included more subtle measures such as parental involvement in school, parents' and students' educational aspirations, students' academic self concept, amount of homework completed, attitudes to school and a wide range of educational risk factors, as well as school and neighbourhood deprivation. This doubled the predictive power of the model. However model $\mathrm{V}$ could not fully account for the low attainment of the Pakistani group and was particularly poor at explaining the low attainment of Black Caribbean and Black African groups. Controlling for these parental and student variables substantially depressed the attainment of all minority ethnic groups relative to White British students. Minority ethnic groups were generally more advantaged than White British students on many of these parental and student variables but they did not see the proportionately greater attainment expected.

None of the models were able to account for the poor attainment of the Black Caribbean group. In terms of social class and mothers educational qualifications, Black Caribbean students do not differ markedly from White British students (See Appendix 1). With regard to disadvantaging factors, relative to White British students, Black Caribbean students on average experience 
greater poverty, are more likely to live in rented accommodation, to have identified SEN, to be temporarily excluded from school, are less likely to complete four evenings or more of homework and are more likely to attend schools that are more deprived and live in more deprived neighbourhoods. In terms of advantaging factors relative to White British students, Black Caribbean students (and their parents) have higher educational aspirations, have a more positive attitude to school, a higher academic self concept and are more likely to be actively planning for the future. However, this extensive set of variables does not provide an explanation of the low attainment of the Black Caribbean group.

\section{Ethnic gaps in student progress age 11-14}

Much of the difference between ethnic groups in attainment at age 14 can be accounted for by pre-existing differences at age 11. To address ethnic differences at age 14 a key focus should be on processes occurring during the primary school phase, since the age 14 differences are largely replications of ethnic group differences already apparent at the end of primary school. However there were two ethnic groups of particular interest in that their gaps relative to the White British group actually widen between age 11 and age 14. These are Indian students who pull further ahead of their White British peers than they were at age 11, and Black Caribbean students who fall even further behind their White British peers than they were at age 11.

The greater progress of Indian students is partly explained by advantaging factors in their family and home lives. Indian students are the ethnic group most likely to complete homework five evenings a week (32\% vs. 19\% White British); the group most likely to have a home computer (94\% vs. $90 \%$ ); the group most likely to pay for private lessons ( $25 \%$ vs. $11 \%$ ); the group where parents are most likely to say they always know where their child is when they are out (92\% vs. $82 \%$ ); the group least likely to have a identified SEN (5\% vs. $8 \%$ ); the group least likely to truant ( $8 \%$ vs. $16 \%$ ); the group least likely to have had social services or EWS contact (3.5\% vs. $8 \%$ ), and lastly, the group least likely to have been excluded from school (4\% vs. $11 \%$ ). Against this there are also disadvantaging factors, for example only $28 \%$ of Indian students are from the top two social classes compared to $41 \%$ of White British students, the mothers of $46 \%$ of the Indian students had no educational qualifications compared to $16 \%$ of White British students, they are more likely to attend the most disadvantaged schools $(18 \%$ vs $6 \%$ White British students) and to live in more deprived neighbourhoods (35\% in the most disadvantaged quartile and only $13 \%$ in the least disadvantaged quartile). These factors account for a large part, but not all, of the better progress of Indian students. It would seem that high parental and student aspirations and hard work, as indicated in the variables above, offset the disadvantaging effects of social and economic circumstances. These are pointers to 
'protective factors' in relation to the educational attainment and progress that have also been suggested for British Chinese students (e.g., Francis \& Archer, 2005) and Asian Americans (Yan \& Lin, 2005).

In contrast, the measured contextual factors do not account for the poor progress made by the Black Caribbean group which remained at -0.78 points. Expressed in NC months of progress, this indicates Black Caribbean students made around three months less educational progress than would be predicted from their prior attainment and all other student, family school and neighbourhood factors. In terms of social class and mothers' educational qualifications, differences between Black Caribbean and White British groups are relatively small. Black Caribbean students are substantially more likely to live in single parent households, but this variable was not significantly related to educational progress. Relative to White British students Black Caribbean students on average experience greater poverty, live in more deprived neighbourhoods, are more likely to have identified SEN, more likely to be excluded from school and were the group that completed the least homework. However these factors do not appear to account for their poor educational progress.

\section{Explanations of ethnic gaps}

Phillips et al. (1998) report that socio-economic status, including racial disparities in family income, wealth, parental education and school resources, explain only about a third of the black-white test score gap for six year olds, and conclude that "reducing economic inequality between black and white parents would probably not reduce the black-white gap much" (p138). The current research suggest similar conclusions may be reached for some UK minority ethnic groups, since the broad range of SES variables could not explain the low attainment of the Black Caribbean group. Increasingly there is a move to explaining the ethnic group variation in attainment that remains after the effects of parental social class and/or maternal education are statistically removed. For example Phillips et al. (1998) also report that also including differences in parenting practices explained up to two-thirds of the black-white test gap of six year olds in the US, and the EPPE study in the UK also reveals the importance of parenting practices in the attainment and progress of young children age three to age seven (Sylva et al., 2004). Parenting practices tend to have their strongest impact on the attainment of young children and a smaller impact on older students, but the current study suggests that variables such as parents' educational aspirations for their children, provision of educational resources and involvement with school are also important in understanding attainment at age 14, since they improve the amount of variance in educational attainment that can be explained from onequarter to one-third, relative to socio-economic factors alone. However, paradoxically including these variables generally serves to increase the ethnic gaps relative to White British students, 
since the higher aspirations and motivations among many ethnic minorities do not seem to return the proportional gains in terms of attainment that they do for White British students. Thus while social class and its correlates are important predictors of educational attainment they have limited success in explaining the differences in attainment between White British and the Black Caribbean and Black African groups.

It is therefore necessary to look at wider explanations of ethnic group differences in attainment, beyond those captured by the specific variables described above. For example it has been argued that the perceptions of teachers, acquired in the staffroom and the classroom through disciplinary problems with previous students, engender low expectations about the behaviour and academic potential of Black Caribbean students and can lead teachers to interpret certain behaviours more negatively than similar behaviour from White British students (Gillborn, 1990). Students are assumed to react to this discrimination by becoming demotivated or confrontational. This reinforces the social stereotyping by teachers and a vicious spiral ensues. In addition, the concept of indirect or 'institutional racism' has also become prominent, moving beyond individualistic conscious intent to encompass organizational arrangements that may have nothing to do with ethnicity directly, but may nevertheless have disproportionate negative impacts on some ethnic groups (Gibson \& Youdell, 2000). Other authors argue that racism, at least in the overt sense, cannot be a complete explanation for ethnic group differences in attainment. Modood (2003) argues "If racism leads to victims being turned off school and dropping out, why do Asian men and women have such high staying-on rates and make academic progress? While recognizing that there are differences in the racism experienced by Caribbean and Asian groups, Asian students experience more frequent and more violent racial harassment from other students than do Caribbean students (yet) this high level peer racism and bullying does not stop Asian students from persisting with high levels of motivation and performance" (Modood, 2003, p58). This does not discount the possibility of social stereotyping or institutional racism against some ethnic groups, but does highlight the importance of considering how well general explanations apply to different minority ethnic groups.

A further category of explanations allows that differences in attainment are at least partially to do with what students bring into the school with them. In explaining the relatively high attainment of Asian Americans, Caplan et al. (1991) argue that Asian Americans have a cultural understanding that prioritizes self-reliance and achievement and that Asian American youth felt it was their responsibility to the family to do well in school. Francis and Archer (2005) in their study of British Chinese students and parents, similarly point to the high value placed on education by parents, coupled with a strong cultural tradition of respect for one's elders, which facilitates the transmission of high educational aspiration from parents to children, and that 
students derive positive self-esteem from constructing themselves as good students. Similar arguments are made in relation to Indian and to 'African Asian' groups in the UK (Modood, 2003). Cultural explanations are also proposed for the low attainment of some minority ethnic groups. For example, Sewell (1997) observes that Black Caribbean boys may experience considerable pressure by their peers to adopt the norms of an 'urban' or 'street' subculture. More credence is given to unruly behaviour with teachers and antagonistic behaviour with other students than to high achievement or effort to succeed, particularly at secondary school (Haynes et al., 2006). A highly influential paper by Fordham and Ogbu (1986) argues that notions of 'acting White' or 'acting Black' become identified in opposition to one another. Hence because acting White includes doing well at school, acting Black necessarily implies not doing well in school. Aspects of this view have been reflected in concerns about the development of 'gangsta' culture and the absence of positive Black male role models at home as well as in schools (e.g. Abbott, 2002). However there is variable empirical support for Fordham and Ogbu's ethnographic claims when tested on wide and representative samples (e.g. Cook \& Ludwig, 1998; Fryer \& Torelli, 2005).

In conclusion, the results indicate the low attainment and poor progress of Black Caribbean students cannot be accounted for by social class or indeed by a wide range of student, family, school and contextual variables. The results mitigate against common explanations of Black Caribbean-White British gap related to socio-economic deprivation, parental involvement or student attitudes to school. Other explanations involving teacher expectations, institutional racism and cultural differences have been introduced. In relation to these claims a further analysis of the LSYPE data in relation to school practices, particularly entry to different tiers in national tests, is reported in a separate paper (Strand, 2009). This suggests that in-school factors, such as teacher expectations, do play a significant part in understanding the relative gap for Black Caribbean students.

\section{References}

Abbott, D. (2002). Teachers are failing black boys. The Observer, $6^{\text {th }}$ January 2002. http://education.guardian.co.uk/racism/story/0,629469,00.html

Caplan, C., Choy, M., \& Whitmore, J. (1991). Children of the boat people: A study of educational success. Ann Arbour: University of Michigan Press.

Coleman, J. S. (1966). Equality of educational opportunity. Washington: Office of Education, US Department of Health, Education and Welfare. 
Cook, P. J., \& Ludwig, J (1998). The burden of "acting white": Do black adolescents disparage academic achievement? In Jenks, C. \& Philips, M (Eds). The Black-White test score gap. Washington: Brookings Institution Press.

Demack, S., Drew, D., \& Grimsley, M. (2000). Minding the gap: Ethnic, gender and social class differences in attainment at 16, 1988-95. Race, Ethnicity and Education, 3(2), 117-143.

DfES (2006). Ethnicity and education. London: DfES. Available of the world wide web at: http://publications.teachernet.gov.uk/eOrderingDownload/DFES-0208-2006.pdf [accessed 27th June 2007).

Fordham, S. \& Ogbu, J. (1986). Black students school success: Coping with the burden of 'acting White'. Urban Review, 18, (3), 176-206.

Francis B. \& Archer L. (2005) British-Chinese students' and parents' constructions of the value of education, British Educational Research Journal, 31, (1), 89-108.

Fryer, R. G., \& Levitt, S. D. (2004). Understanding the Black-White Test Score Gap in the First Two Years of School. Review of Economics and Statistics, 86(2), 447-464.

Fryer, R. G., \& Torelli, P. (2005). An empirical analysis of 'Acting White': NBER Working Paper Series, Vol. w11334. Available at SSRN: http://ssrn.com/abstract=723303.

Gillborn, D. (1990) Race, Ethnicity and Education: Teaching and learning in multi-cultural schools. London: Unwin Hyman.

Gillborn, D. \& Youdell, D. (2000). Rationing education: Policy, practice, reform and equity. Buckingham: Open University Press.

Haynes, J., Tikly, L. \& Caballero, C. (2006). The barriers to achievement for White/Caribbean students in English schools. British Journal of Sociology of Education, 27, (5), 569-583.

Hedges, L. V., \& Nowell, A. (1998). Black-White test score convergence since 1965. In C. Jenks \& M. Phillips (Eds.), The Black-White test score gap (pp. 149-181). Washington, DC: Brooking Institution Press.

Jencks, C. \& Philips, M. (1998). The Black-White test score gap. Washington: Brookings Institution Press.

Kenway, P., \& Palmer, G. (2007). Poverty among ethnic groups: How and why does it differ? York: Joseph Rowntree Foundation.

KewallRamani, A., Gilbertson, L., Fox, M., \& Provasnik, S. (2007). Status and trends in the education of racial and ethnic minorities (NCES 2007-039). Washington, DC: National Centre for Educational Statistics, Institute of Educational Sciences, US Department of Education.

McLoyd, V. C. (1998). Socioeconomic disadvantage and child development. American Psychologist, 53(2), 185-203. 
Modood, T. (2003). Ethnic differentials in educational performance. In Mason, D. (2003) (Ed). Explaining ethnic differences: Changing patterns of disadvantage in Britain. Bristol: Open Press.

Phillips, M., Brooks-Gunn, J., Duncan, G., Klebanov, P., \& Crane, J. (1998). Family background, parenting practices, and the Black-White test score gap. In C. Jenks \& $M$. Phillips (Eds.), The Black-White test score gap (pp. 229-272). Washington DC: Brookings Institution Press.

Powdatheee, N. Levacic, R. \& Vignoles, A. (2006). The influence of family and social factors on educational attainment: A review of UK quantitative studies. London: Institute of Education.

Sewell, T. (1997). Black masculinity and schooling: How black boys survive modern schooling. Stoke on Trent: Trentham books.

Sirin, S. R. (2005). Socioeconomic status and academic achievement: A meta-analytic review of research. Review of Educational Research, 75, (32), 417-453.

Strand, S. (1999). Ethnic group, sex and economic disadvantage: Associations with students' educational progress from Baseline to the end of Key Stage 1. British Educational Research Journal, 25, (2), 179-202.

Strand, S. (2007). Minority ethnic students in the Longitudinal Study of Young People in England. DCSF Research Report RR-002. London: Department for Children, Schools and Families. Available online at: http://www.dfes.gov.uk/research/data/uploadfiles/DCSF-RR002.pdf (128 pages).

Strand, S. (2009). In-school factors and the White British-Black Caribbean attainment gap: Test, tiers and unintended consequences of assessment practice. Paper presented at the Annual Conference of the American Educational Research Association, San Diego, California, 13-17 April 2009.

Strand, S. \& Winston, J. (2008). Educational aspirations in inner city schools. Educational Studies, 34, (4), 249-267.

Swann Report (1985). Education for all. The report of the committee of enquiry into the education of children from ethnic minority groups. London: HMSO.

Sylva, K., Melhuish, E., Sammons, P., Siraj-Blatchford, I. \& Taggart, B. (2004). The Effective Provision of Pre-School Education (EPPE) project: Final Report. London: Department for Education and Skills.

TGAT (1988). Task Group on Assessment and Testing. London: Department for Education and Science.

US Census Bureau (2006). Current population reports, p60-231, Income, poverty and health insurance in the United States 2005: US Government Printing Office: Washington DC. Retrieved from the www at http://www.census.gov/prod/2006pubs/p60-231.pdf on 7th July 2007. 
Yan, W., \& Lin, Q. (2005). Parent Involvement and Mathematics Achievement: Contrast Across Racial and Ethnic Groups. Journal of Educational Research, 99(2), 116-127. 
Table 1: $\quad$ Mean and SE of age 14 average test score by ethnic group, gender and social class

\begin{tabular}{|c|c|c|c|c|}
\hline Variable & Value & Mean & SE & $\begin{array}{r}\text { Un- } \\
\text { weighted } \\
\mathrm{N}\end{array}$ \\
\hline \multirow[t]{9}{*}{ Ethnic group } & White British & 33.9 & .12 & 9406 \\
\hline & Mixed heritage & 33.4 & .24 & 754 \\
\hline & Indian & 34.4 & .26 & 990 \\
\hline & Pakistani & 30.8 & .23 & 918 \\
\hline & Bangladeshi & 31.0 & .27 & 703 \\
\hline & Black Caribbean & 30.6 & .26 & 558 \\
\hline & Black African & 30.9 & .29 & 577 \\
\hline & Any other group & 33.6 & .31 & 597 \\
\hline & Gap (White British vs. lowest minority) & 3.3 & & \\
\hline \multirow[t]{3}{*}{ Gender } & Male & 33.3 & 0.14 & 7378 \\
\hline & female & 34.1 & 0.12 & 7140 \\
\hline & Gap & 0.8 & & \\
\hline Social class & Higher managerial and professional & 38.1 & 0.18 & 1378 \\
\hline \multirow[t]{8}{*}{ of the home } & Lower managerial and professional & 36.1 & 0.13 & 2851 \\
\hline & Intermediate occupations & 34.4 & 0.19 & 899 \\
\hline & Small employers and own account workers & 34.0 & 0.16 & 1585 \\
\hline & Lower supervisory and technical & 32.7 & 0.14 & 1421 \\
\hline & Semi-routine occupations & 31.5 & 0.16 & 1580 \\
\hline & Routine occupations & 30.5 & 0.19 & 1367 \\
\hline & Never worked/long term unemployed & 28.5 & 0.23 & 1019 \\
\hline & Gap (highest vs. lowest) & 9.6 & & \\
\hline Grand m & & 33.5 & $6.7^{(a)}$ & 14503 \\
\hline
\end{tabular}

Notes. Data are weighted by combined design and non-response weights. The overall sample and ethnic group mean scores matches the relevant national averages for 2004 indicating the sample is representative of England in terms of attainment at age 14. (a) Standard Deviation. 
Table 2: Regression models of age 14 average points score

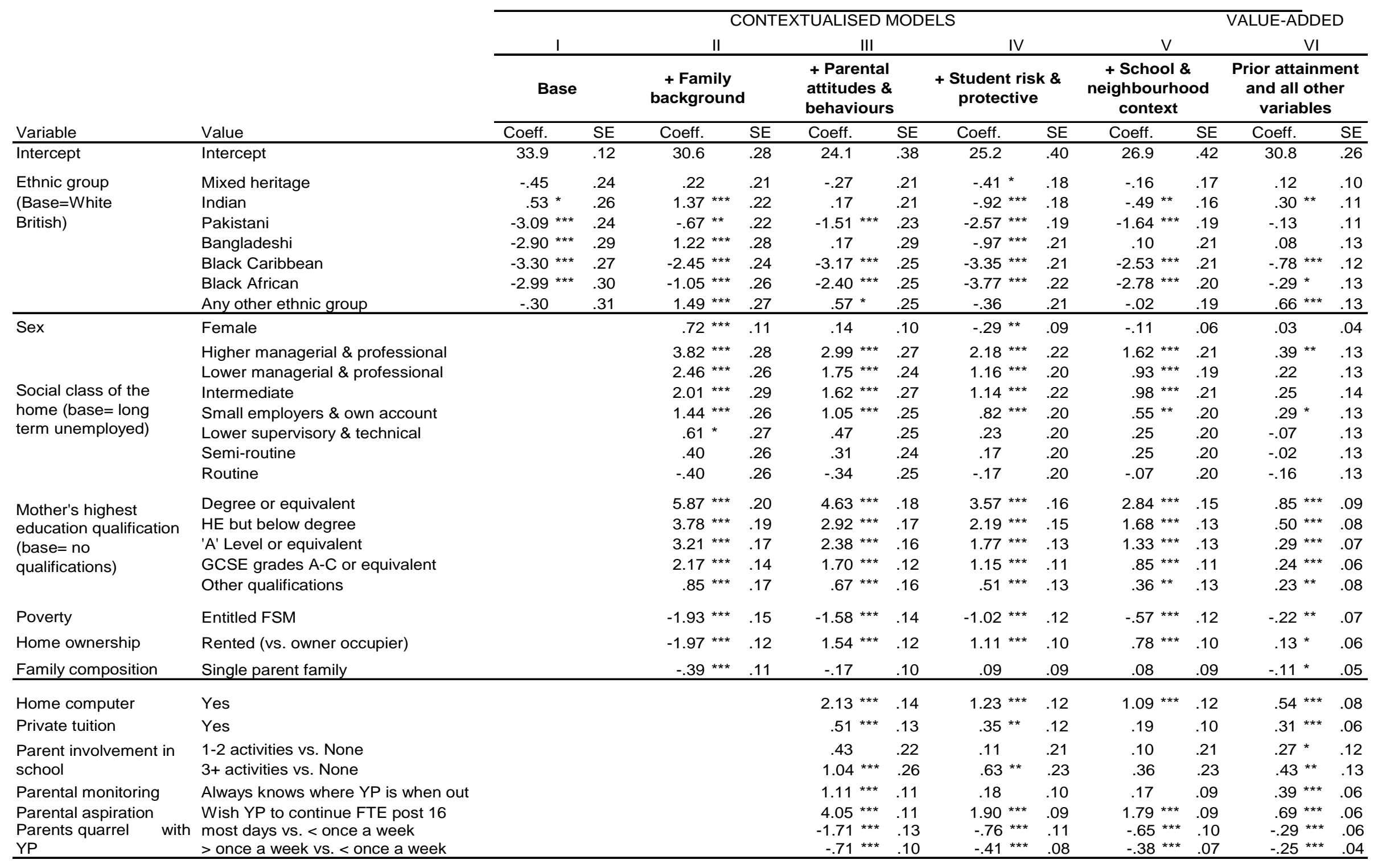


Table 2: Regression models of age 14 average points score (continued)

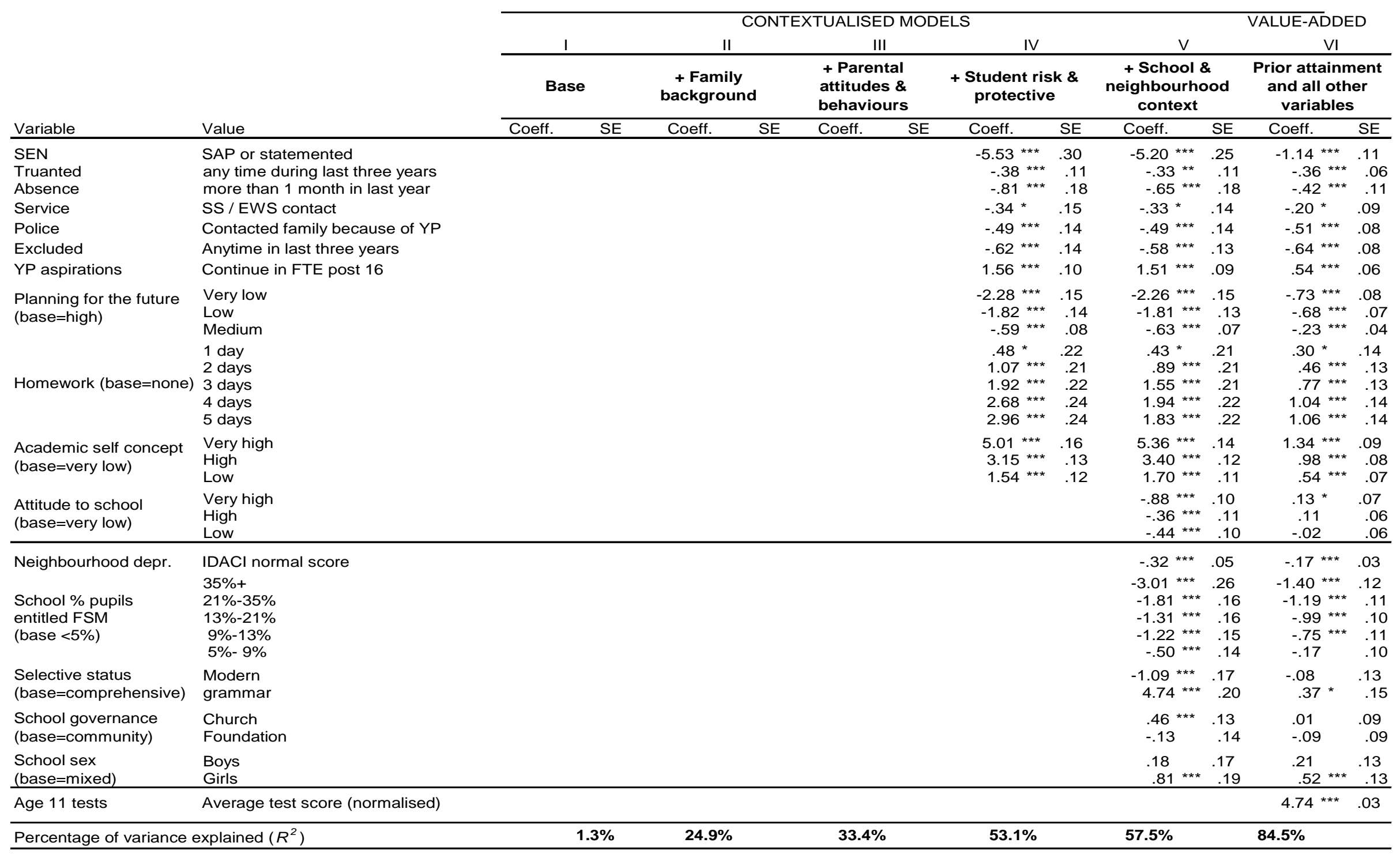

The limits of social class ... 
Table 3: Mean Age 11 score and progress age 11-14 by ethnic group

\begin{tabular}{lccccccc}
\hline & \multicolumn{3}{c}{ Age 11\% at expected } & \multicolumn{2}{c}{ Mean age 11 } & \multicolumn{2}{c}{ Progress age } \\
test score & \multicolumn{2}{c}{$\mathbf{1 1 ~ - 1 4}^{(b)}$} \\
Ethnic group & English & maths & science & Mean & SD & Mean & SE \\
\hline White British & 75.2 & 71.5 & 88.6 & 0.06 & 0.99 & - & - \\
Mixed heritage & 74.8 & 68.2 & 87.1 & 0.03 & 1.02 & -0.10 & 0.11 \\
Indian & 77.3 & 72.9 & 83.9 & 0.03 & 1.00 & $0.80^{* *}$ & 0.12 \\
Pakistani & 63.1 & 55.7 & 71.6 & $-0.45^{* *}$ & 0.96 & 0.09 & 0.13 \\
Bangladeshi & 65.7 & 59.6 & 76.4 & $-0.30^{* *}$ & 1.03 & -0.30 & 0.15 \\
Black Caribbean & 67.2 & 54.5 & 80.2 & $-0.33^{* *}$ & 0.95 & $-0.77^{* *}$ & 0.14 \\
Black African & 68.2 & 59.2 & 79.7 & $-0.25^{* *}$ & 1.04 & 0.30 & 0.15 \\
Any Other group & 69.9 & 66.4 & 82.4 & 0.00 & 1.12 & 0.85 & 0.15 \\
\hline Total & 75.0 & 70.0 & 88.0 & 0.04 & 1.00 & - & - \\
\hline
\end{tabular}

Notes: (a) At age 11 students are expected to achieve Level 4 or above in the National Curriculum. (b) The progress measure includes each pupil's age 11 score and ethnic group as predictors in a multiple regression for age 14 average test score. The figures give the give contrasts against the White British group. ${ }^{* *} p<.001$. 
Figure 1: Regression coefficients for minority ethnic groups relative to White British students in five regression models of educational attainment at age 14

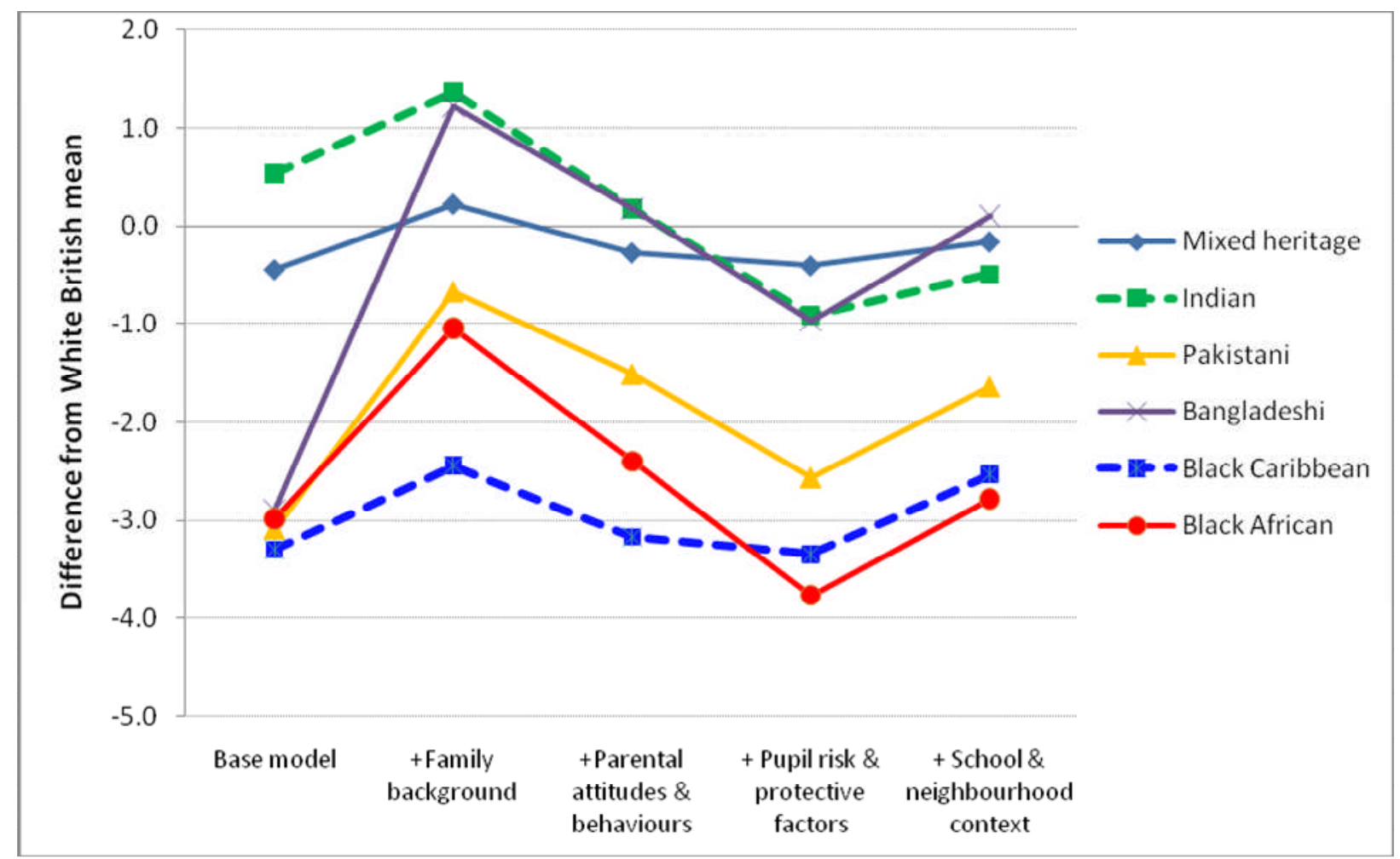

Note: White British students are the reference group and indicated by a value of zero in each model. 


\section{APPENDIX 1: Definition of explanatory variables derived from LSYPE}

\section{Family background}

Ethnic group: Information on students' ethnic group was collected through self-identification from 16 ethnic categories (plus don't know/refused). The rationale for the LSYPE sampling strategy was to focus on the attainment of the six main minority ethnic groups and White British students, hence ethnic group was collapsed into seven categories plus a generic 'any other group'. The seven categories were White British, Mixed heritage, Indian, Pakistani, Bangladeshi, Black Caribbean and Black African which together these groups accounted for $96 \%$ of all students interviewed.

Socio-economic classification of the home (SEC): The SEC of the head of the household was coded by matching their occupation/size of organisation using the Office of National Statistics eight SEC analytic classes, ranging from higher managerial and professional occupations through to never worked or unemployed for the last six months or more.

Mothers' highest educational qualifications: The highest educational qualifications of the student's mother was measured on a six point scale ranging from degree or above through to no educational qualifications.

Entitlement to a Free School Meal (FSM): This is a widely used measure of family poverty since only students from families claiming state benefits are eligible for FSM.

Home ownership: A binary indicator of whether the family owned or rented their home. Home ownership provides a measure of socio-economic status in England where many families aspire to own their own home and there is relatively little Local Authority or social housing.

Family composition: students living in a household with a single adult were contrasted with those living in a household with more than one adult.

\section{$\underline{\text { Parental attitudes and behaviours }}$}

Parents educational aspirations for the young person: The main parent was asked what they would like their child to do when s/he reached school leaving age 16 . This variable identifies students whose parents wished them to remaining in full-time education (FTE) beyond the official school leaving age of 16 years.

Provision of educational resources: There were two measures (a) whether the family provided a home computer for the students use, and (b) whether the family paid for private lessons in subjects that are taught in school as part of the National Curriculum.

Parental involvement in school: The parent interview included questions on parents' involvement in education and school activities. Variables that offered little discrimination 
were ignored (e.g. 98.2\% of parents talked to their children about their reports). Activities that required special knowledge or resources were also excluded (e.g. help out with teacher assessment, host an exchange student, donations or financial support to the school, employed at school, help with special interest groups like sport or drama). Following this process seven binary outcomes were created (attended a parents evening in the last 12 months; talked to teacher about the child in the last 12 months; helped out in class; helped elsewhere in the school e.g. library; helped with fundraising activities, involved in Parent Teacher association and acted as school or parent governor. A summary variable was created which recorded parent involved in one, two or three or more activities, contrasted again none.

Parental supervision: A binary indicator of whether the main parent reported they 'always knew where the young person was when s/he was out' or not.

Family discord: The frequency with which parent reported quarrelling with the student, with 'most days' and 'more than once a week' contrasted against 'less than once a week'.

\section{$\underline{\text { Student risk and protective factors }}$}

Special Educational Needs (SEN): This was a binary variable to identify students who were either at School Action Plus or had a statement for SEN, both of which require the involvement of an external agency not just school based identification, contrasted with those with no such identification.

Truancy: A binary indicator of whether the student has truanted at any time in last 12 months.

Long term absence: a binary indicator of whether the student had been absent from the school for one month or more in the past 12 months.

Service involvement: A binary indicator of whether the parents reported they had ever been contacted by Social Services or the Educational Welfare Service about the student's behaviour. Also a separate measure of police involvement where the parents had been contacted by the police because of something the student has done.

Excluded: A binary indicator of whether the student has been either temporarily or permanently excluded in the last three years.

Student's educational aspirations: A binary indicator of whether the student intends to remain in full-time education (FTE) after age 16 (the end of compulsory schooling) or not.

Planning for the future: students were asked three questions 'I don't think much about what I will do in the future', 'I'll just wait and see where I end up' and 'having a job/career is important to me' each measured on a five point Likert scale. A short scale was created which had low but acceptable internal consistency (Cronbach's alpha $=.52$ ). For the purpose of analysis four score bands were used. 
Homework: The number of evenings a week on which the young person reported they usually completed homework, ranging from none through to five.

Academic self concept: A scale measuring academic self concept was created from seven items each measured on a five point Likert scale. The seven items were: I get good marks for my work, how good do you think you are at school work, how good do your teachers think you are at school work, and how good do you think you are at English, mathematics, science and ICT respectively. The scores were summed to create a short scale which had good internal consistency (Cronbach's alpha $=.73$ ). The scores were divided into four score bands.

Attitude to school: This was measured by nine questions relating to attitudes to school, teachers and lessons each coded on a five point Likert scale. Items included questions such as "I am happy when I am at school"; "I work as hard as I can in school", "the work I do in lessons is a waste of time". For the purpose of the analysis the continuous scores were coded into quartile bands and contrasted against the least positive band.

\section{$\underline{\text { School and neighbourhood context }}$}

A wide range of school level variables were tested but only the four variables listed below, plus neighbourhood deprivation, were significantly related to attainment.

Selective status: Comprehensive schools do not select by ability and take in the whole ability range. Grammar schools select by ability, taking the more able children from a geographical area based on their scores on a reasoning test at age 11. Secondary modern schools cater for the students in selective areas who are not selected by the grammar schools.

School type: Church schools and Foundation schools were contrasted with community (nondenominational) schools.

School sex: Schools were coded as co-educational, singles sex boys or single sex girls.

School deprivation: The percentage of students in the school entitled to FSM was used as an indicator of the relative deprivation of the school. Schools were placed into six bands ranging from the least deprived ( $<5 \%$ entitled to $\mathrm{FSM}$ ) to the most deprived ( $35 \%$ or more entitled to FSM). These bandings are those used by the DCSF in analysis of school performance.

Neighbourhood deprivation: The Income Deprivation affecting Children Index (IDACI) is produced by central government and measures the proportion of children under the age of 16 in an area living in low income households. The measure is focused on disadvantage and has a wide base including families in receipt of income support, job 
seekers allowance and working families tax credit/disabled persons tax credit (for those below $60 \%$ of national median income). The indicator is available for very localised areas called super output areas (SOA) of which there are 32,000 in England, each containing approximately 1,500 people and 200 children $(S D=70)$. Scores were normalised to a mean of zero and SD of 1 where higher scores indicated greater neighbourhood deprivation. 
APPENDIX 2: Contextual variables by ethnic group

\begin{tabular}{|c|c|c|c|c|c|c|c|c|c|}
\hline Variable & Value & $\begin{array}{l}\text { White } \\
\text { British }\end{array}$ & $\begin{array}{c}\text { Mixed } \\
\text { her- } \\
\text { itage } \\
\end{array}$ & Indian & $\begin{array}{l}\text { Paki- } \\
\text { stani }\end{array}$ & $\begin{array}{l}\text { Bangl- } \\
\text { adeshi }\end{array}$ & $\begin{array}{c}\text { Black } \\
\text { Caribb } \\
\text { ean }\end{array}$ & $\begin{array}{c}\text { Black } \\
\text { Africa } \\
n\end{array}$ & $\begin{array}{l}\text { Any } \\
\text { other } \\
\text { group }\end{array}$ \\
\hline \multirow[t]{2}{*}{ Gender } & Male & $51.5 \%$ & $48.7 \%$ & $52.6 \%$ & $50.8 \%$ & $43.8 \%$ & $49.6 \%$ & $49.5 \%$ & $51.1 \%$ \\
\hline & Female & $48.5 \%$ & $51.3 \%$ & $47.4 \%$ & $49.2 \%$ & $56.2 \%$ & $50.4 \%$ & $50.5 \%$ & $48.9 \%$ \\
\hline \multirow{9}{*}{$\begin{array}{l}\text { Social class } \\
\text { of the home }\end{array}$} & Missing & $15.1 \%$ & $16.3 \%$ & $18.6 \%$ & $20.7 \%$ & $27.3 \%$ & $17.2 \%$ & $18.9 \%$ & $21.4 \%$ \\
\hline & $\begin{array}{l}\text { Higher managerial and } \\
\text { professional }\end{array}$ & $14.7 \%$ & $13.5 \%$ & $10.4 \%$ & $7.0 \%$ & $.6 \%$ & $6.6 \%$ & $11.5 \%$ & $17.5 \%$ \\
\hline & $\begin{array}{l}\text { Lower managerial and } \\
\text { professional }\end{array}$ & $27.0 \%$ & $29.1 \%$ & $18.8 \%$ & $12.4 \%$ & $8.2 \%$ & $30.1 \%$ & $23.9 \%$ & $18.9 \%$ \\
\hline & Intermediate & $7.4 \%$ & $7.7 \%$ & $7.2 \%$ & $3.5 \%$ & $.9 \%$ & $15.5 \%$ & $8.9 \%$ & $4.2 \%$ \\
\hline & $\begin{array}{l}\text { Small employers and } \\
\text { own account }\end{array}$ & $12.5 \%$ & $10.0 \%$ & $18.2 \%$ & $26.2 \%$ & $11.9 \%$ & $6.9 \%$ & $3.6 \%$ & $17.7 \%$ \\
\hline & $\begin{array}{l}\text { Lower supervisory and } \\
\text { technical }\end{array}$ & $12.2 \%$ & $10.2 \%$ & $10.5 \%$ & $4.5 \%$ & $14.5 \%$ & $10.8 \%$ & $5.1 \%$ & $9.1 \%$ \\
\hline & Semi-routine & $12.3 \%$ & $13.5 \%$ & $13.7 \%$ & $9.4 \%$ & $11.8 \%$ & $14.3 \%$ & $14.9 \%$ & $9.6 \%$ \\
\hline & Routine occupations & $10.6 \%$ & $7.8 \%$ & $14.4 \%$ & $13.7 \%$ & $12.1 \%$ & $8.3 \%$ & $6.1 \%$ & $9.2 \%$ \\
\hline & $\begin{array}{l}\text { Never worked/long term } \\
\text { unemployed }\end{array}$ & $3.4 \%$ & $8.1 \%$ & $6.8 \%$ & $23.3 \%$ & $40.0 \%$ & $7.6 \%$ & $25.9 \%$ & $13.9 \%$ \\
\hline \multirow{7}{*}{$\begin{array}{l}\text { Mothers } \\
\text { highest } \\
\text { educational } \\
\text { qualification }\end{array}$} & Missing & $4.8 \%$ & $6.3 \%$ & $4.2 \%$ & $10.0 \%$ & $10.5 \%$ & $8.9 \%$ & $9.4 \%$ & $6.6 \%$ \\
\hline & Degree or equivalent & $11.5 \%$ & $15.2 \%$ & $8.5 \%$ & $7.8 \%$ & $1.0 \%$ & $9.5 \%$ & $16.5 \%$ & $11.7 \%$ \\
\hline & HE below degree level & $13.3 \%$ & $17.3 \%$ & $6.3 \%$ & $4.0 \%$ & $1.5 \%$ & $23.8 \%$ & $16.8 \%$ & $7.9 \%$ \\
\hline & 'A' level or equivalent & $14.4 \%$ & $12.1 \%$ & $9.1 \%$ & $5.9 \%$ & $2.1 \%$ & $15.9 \%$ & $9.9 \%$ & $7.7 \%$ \\
\hline & GCSE grades $A-C$ equiv & $34.6 \%$ & $23.8 \%$ & $25.2 \%$ & $9.7 \%$ & $7.3 \%$ & $29.1 \%$ & $14.8 \%$ & $14.3 \%$ \\
\hline & Other qualifications & $10.6 \%$ & $6.7 \%$ & $8.1 \%$ & $4.3 \%$ & $2.6 \%$ & $11.2 \%$ & $2.9 \%$ & $8.9 \%$ \\
\hline & No qualification & $15.6 \%$ & $25.0 \%$ & $42.8 \%$ & $68.2 \%$ & $85.5 \%$ & $10.6 \%$ & $39.1 \%$ & $49.5 \%$ \\
\hline \multirow{3}{*}{$\begin{array}{l}\text { Entitled to a } \\
\text { FSM }\end{array}$} & Missing & $.1 \%$ & $.1 \%$ & $.3 \%$ & $.6 \%$ & $.3 \%$ & $.2 \%$ & $1.2 \%$ & $.3 \%$ \\
\hline & No & $87.2 \%$ & $74.9 \%$ & $86.2 \%$ & $61.9 \%$ & $41.4 \%$ & $73.8 \%$ & $58.6 \%$ & $70.4 \%$ \\
\hline & Yes & $12.8 \%$ & $25.1 \%$ & $13.8 \%$ & $38.1 \%$ & $58.6 \%$ & $26.2 \%$ & $41.4 \%$ & $29.6 \%$ \\
\hline \multirow{3}{*}{$\begin{array}{l}\text { Owner } \\
\text { occupier }\end{array}$} & Missing & $1.4 \%$ & $1.6 \%$ & $1.1 \%$ & $2.4 \%$ & $1.6 \%$ & $2.6 \%$ & $2.7 \%$ & $3.1 \%$ \\
\hline & Rented & $25.5 \%$ & $41.9 \%$ & $13.7 \%$ & $21.5 \%$ & $54.2 \%$ & $55.7 \%$ & $68.2 \%$ & $47.5 \%$ \\
\hline & Owned & $74.5 \%$ & $58.1 \%$ & $86.3 \%$ & $78.5 \%$ & $45.8 \%$ & $44.3 \%$ & $31.8 \%$ & $52.5 \%$ \\
\hline \multirow{3}{*}{$\begin{array}{l}\text { Single parent } \\
\text { household }\end{array}$} & Missing & $.6 \%$ & $.7 \%$ & $.8 \%$ & $1.0 \%$ & $1.3 \%$ & $1.6 \%$ & $.5 \%$ & $1.4 \%$ \\
\hline & No & $77.2 \%$ & $58.5 \%$ & $87.8 \%$ & $84.7 \%$ & $85.2 \%$ & $43.1 \%$ & $55.7 \%$ & $78.1 \%$ \\
\hline & Yes & $22.8 \%$ & $41.5 \%$ & $12.2 \%$ & $15.3 \%$ & $14.8 \%$ & $56.9 \%$ & $44.3 \%$ & $21.9 \%$ \\
\hline \multirow{3}{*}{$\begin{array}{l}\text { Household } \\
\text { has home } \\
\text { computer }\end{array}$} & Missing & $.1 \%$ & $.0 \%$ & $.1 \%$ & $.0 \%$ & $.0 \%$ & $.0 \%$ & $.0 \%$ & $.0 \%$ \\
\hline & No & $10.1 \%$ & $15.2 \%$ & $6.0 \%$ & $18.2 \%$ & $19.3 \%$ & $19.0 \%$ & $13.6 \%$ & $13.0 \%$ \\
\hline & Yes & $89.9 \%$ & $84.8 \%$ & $94.0 \%$ & $81.8 \%$ & $80.7 \%$ & $81.0 \%$ & $86.4 \%$ & $87.0 \%$ \\
\hline \multirow[t]{3}{*}{ Private tuition } & Missing & $.0 \%$ & $.1 \%$ & $.0 \%$ & $.1 \%$ & $.1 \%$ & $.0 \%$ & $.5 \%$ & $.0 \%$ \\
\hline & No & $88.9 \%$ & $83.1 \%$ & $75.2 \%$ & $85.8 \%$ & $88.1 \%$ & $85.9 \%$ & $78.4 \%$ & $80.0 \%$ \\
\hline & Yes & $11.1 \%$ & $16.9 \%$ & $24.8 \%$ & $14.2 \%$ & $11.9 \%$ & $14.1 \%$ & $21.6 \%$ & $20.0 \%$ \\
\hline \multirow{3}{*}{$\begin{array}{l}\text { Parental } \\
\text { involvement } \\
\text { in school }\end{array}$} & 1-2 activities & $87.1 \%$ & $87.0 \%$ & $87.7 \%$ & $86.7 \%$ & $84.9 \%$ & $89.1 \%$ & $82.4 \%$ & $84.6 \%$ \\
\hline & $3+$ activities & $9.8 \%$ & $10.6 \%$ & $9.0 \%$ & $8.3 \%$ & $6.3 \%$ & $9.1 \%$ & $14.2 \%$ & $11.4 \%$ \\
\hline & 0 activities & $3.2 \%$ & $2.4 \%$ & $3.3 \%$ & $5.0 \%$ & $8.8 \%$ & $1.8 \%$ & $3.4 \%$ & $4.1 \%$ \\
\hline \multirow{3}{*}{$\begin{array}{l}\text { Parental } \\
\text { supervision }\end{array}$} & Missing & $.1 \%$ & $.1 \%$ & $.0 \%$ & $.1 \%$ & $.1 \%$ & $.0 \%$ & $.2 \%$ & $.0 \%$ \\
\hline & Does not always know & $18.4 \%$ & $18.1 \%$ & $8.3 \%$ & $11.4 \%$ & $14.0 \%$ & $18.4 \%$ & $9.7 \%$ & $11.3 \%$ \\
\hline & $\begin{array}{l}\text { Always knows where } \\
\text { child is when out }\end{array}$ & $81.6 \%$ & $81.9 \%$ & $91.7 \%$ & $88.6 \%$ & $86.0 \%$ & $81.6 \%$ & $90.3 \%$ & $88.7 \%$ \\
\hline \multirow{3}{*}{$\begin{array}{l}\text { Parent wishes } \\
\text { YP continue } \\
\text { FTE post } 16\end{array}$} & Missing & $.1 \%$ & $.0 \%$ & $.2 \%$ & $.0 \%$ & $.1 \%$ & $.0 \%$ & $.0 \%$ & $.2 \%$ \\
\hline & No & $23.1 \%$ & $12.2 \%$ & $4.9 \%$ & $5.5 \%$ & $5.7 \%$ & $8.0 \%$ & $1.6 \%$ & $8.3 \%$ \\
\hline & Yes & $76.9 \%$ & $87.8 \%$ & $95.1 \%$ & $94.5 \%$ & $94.3 \%$ & $92.0 \%$ & $98.4 \%$ & $91.7 \%$ \\
\hline \multirow{4}{*}{$\begin{array}{l}\text { parent } \\
\text { reported } \\
\text { quarrelling } \\
\text { with YP }\end{array}$} & Missing & $2.5 \%$ & $4.0 \%$ & $16.8 \%$ & $40.2 \%$ & $54.1 \%$ & $5.3 \%$ & $16.9 \%$ & $19.9 \%$ \\
\hline & Most days & $13.6 \%$ & $14.9 \%$ & $9.7 \%$ & $13.6 \%$ & $7.0 \%$ & $12.2 \%$ & $12.0 \%$ & $12.5 \%$ \\
\hline & More than once week & $25.5 \%$ & $20.6 \%$ & $17.1 \%$ & $13.8 \%$ & $11.8 \%$ & $23.9 \%$ & $17.9 \%$ & $16.7 \%$ \\
\hline & Less than once week & $60.9 \%$ & $64.5 \%$ & $73.2 \%$ & $72.6 \%$ & $81.1 \%$ & $63.8 \%$ & $70.1 \%$ & $70.7 \%$ \\
\hline \multirow[t]{3}{*}{ SEN } & Missing & $.1 \%$ & $.1 \%$ & $.3 \%$ & $.6 \%$ & $.3 \%$ & $.2 \%$ & $1.2 \%$ & $.3 \%$ \\
\hline & SAP/Statemented & $8.2 \%$ & $8.5 \%$ & $4.8 \%$ & $7.6 \%$ & $8.9 \%$ & $13.6 \%$ & $6.5 \%$ & $5.7 \%$ \\
\hline & Not SAP/Stat & $91.8 \%$ & $91.5 \%$ & $95.2 \%$ & $92.4 \%$ & $91.1 \%$ & $86.4 \%$ & $93.5 \%$ & $94.3 \%$ \\
\hline \multirow{3}{*}{$\begin{array}{l}\text { truant in last } \\
12 \text { months }\end{array}$} & Missing & $5.5 \%$ & $6.7 \%$ & $7.2 \%$ & $9.5 \%$ & $14.1 \%$ & $5.5 \%$ & $11.2 \%$ & $8.0 \%$ \\
\hline & Yes & $15.9 \%$ & $21.7 \%$ & $8.2 \%$ & $13.6 \%$ & $15.7 \%$ & $19.1 \%$ & $13.1 \%$ & $12.0 \%$ \\
\hline & No & $84.1 \%$ & $78.3 \%$ & $91.8 \%$ & $86.4 \%$ & $84.3 \%$ & $80.9 \%$ & $86.9 \%$ & $88.0 \%$ \\
\hline absent >1 & Missing & $3.6 \%$ & $4.7 \%$ & $16.6 \%$ & $40.6 \%$ & $54.7 \%$ & $6.2 \%$ & $18.5 \%$ & $20.2 \%$ \\
\hline
\end{tabular}




\begin{tabular}{|c|c|c|c|c|c|c|c|c|c|}
\hline Variable & Value & $\begin{array}{l}\text { White } \\
\text { British }\end{array}$ & $\begin{array}{c}\text { Mixed } \\
\text { her- } \\
\text { itage }\end{array}$ & Indian & $\begin{array}{l}\text { Paki- } \\
\text { stani }\end{array}$ & $\begin{array}{l}\text { Bangl- } \\
\text { adeshi }\end{array}$ & $\begin{array}{c}\text { Black } \\
\text { Caribb } \\
\text { ean }\end{array}$ & $\begin{array}{c}\text { Black } \\
\text { Africa } \\
n\end{array}$ & $\begin{array}{l}\text { Any } \\
\text { other } \\
\text { group }\end{array}$ \\
\hline $\begin{array}{l}\text { month in last } \\
\text { year }\end{array}$ & $\begin{array}{l}\text { Yes } \\
\text { No }\end{array}$ & $\begin{array}{r}4.2 \% \\
95.8 \% \\
\end{array}$ & $\begin{array}{r}6.7 \% \\
93.3 \% \\
\end{array}$ & $\begin{array}{r}3.3 \% \\
96.7 \% \\
\end{array}$ & $\begin{array}{r}6.4 \% \\
93.6 \% \\
\end{array}$ & $\begin{array}{r}2.4 \% \\
97.6 \% \\
\end{array}$ & $\begin{array}{r}2.8 \% \\
97.2 \% \\
\end{array}$ & $\begin{array}{r}2.0 \% \\
98.0 \% \\
\end{array}$ & $\begin{array}{r}3.0 \% \\
97.0 \% \\
\end{array}$ \\
\hline Social & Missing & $2.3 \%$ & $4.2 \%$ & $15.9 \%$ & $39.3 \%$ & $53.8 \%$ & $4.6 \%$ & $16.7 \%$ & $19.0 \%$ \\
\hline Services/EWS & Yes & $7.5 \%$ & $9.4 \%$ & $3.4 \%$ & $5.4 \%$ & $4.3 \%$ & $8.8 \%$ & $5.9 \%$ & $5.4 \%$ \\
\hline involvement & No & $92.5 \%$ & $90.6 \%$ & $96.6 \%$ & $94.6 \%$ & $95.7 \%$ & $91.2 \%$ & $94.1 \%$ & $94.6 \%$ \\
\hline $\begin{array}{l}\text { Police } \\
\text { involvement }\end{array}$ & $\begin{array}{l}\text { Missing } \\
\text { Yes } \\
\text { No }\end{array}$ & $\begin{array}{r}2.6 \% \\
8.5 \% \\
91.5 \%\end{array}$ & $\begin{array}{r}4.4 \% \\
10.9 \% \\
89.1 \%\end{array}$ & $\begin{array}{r}16.0 \% \\
2.4 \% \\
97.6 \%\end{array}$ & $\begin{array}{r}39.5 \% \\
2.2 \% \\
97.8 \%\end{array}$ & $\begin{array}{r}53.8 \% \\
2.0 \% \\
98.0 \%\end{array}$ & $\begin{array}{r}5.1 \% \\
4.8 \% \\
95.2 \%\end{array}$ & $\begin{array}{r}17.1 \% \\
4.1 \% \\
95.9 \%\end{array}$ & $\begin{array}{r}19.9 \% \\
3.8 \% \\
96.2 \%\end{array}$ \\
\hline $\begin{array}{l}\text { Excluded in } \\
\text { last } 3 \text { years }\end{array}$ & $\begin{array}{l}\text { Missing } \\
\text { Yes } \\
\text { No }\end{array}$ & $\begin{array}{r}2.2 \% \\
10.5 \% \\
89.5 \% \\
\end{array}$ & $\begin{array}{r}3.9 \% \\
15.5 \% \\
84.5 \% \\
\end{array}$ & $\begin{array}{r}15.8 \% \\
4.0 \% \\
96.0 \% \\
\end{array}$ & $\begin{array}{r}39.2 \% \\
6.9 \% \\
93.1 \%\end{array}$ & $\begin{array}{r}53.8 \% \\
5.1 \% \\
94.9 \%\end{array}$ & $\begin{array}{r}4.6 \% \\
19.8 \% \\
80.2 \% \\
\end{array}$ & $\begin{array}{l}16.4 \% \\
10.9 \% \\
89.1 \% \\
\end{array}$ & $\begin{array}{r}19.0 \% \\
8.5 \% \\
91.5 \% \\
\end{array}$ \\
\hline $\begin{array}{l}\text { YP educ. } \\
\text { aspirations }\end{array}$ & $\begin{array}{l}\text { Leave at 16/DK } \\
\text { Stay in FTE post } 16\end{array}$ & $\begin{array}{l}23.2 \% \\
76.8 \%\end{array}$ & $\begin{array}{l}15.7 \% \\
84.3 \%\end{array}$ & $\begin{array}{r}5.4 \% \\
94.6 \%\end{array}$ & $\begin{array}{r}8.8 \% \\
91.2 \% \\
\end{array}$ & $\begin{array}{r}7.8 \% \\
92.2 \% \\
\end{array}$ & $\begin{array}{l}14.6 \% \\
85.4 \%\end{array}$ & $\begin{array}{r}3.6 \% \\
96.4 \% \\
\end{array}$ & $\begin{array}{l}12.4 \% \\
87.6 \%\end{array}$ \\
\hline $\begin{array}{l}\text { Planning } \\
\text { for the future }\end{array}$ & $\begin{array}{l}\text { Very Low } \\
\text { Low } \\
\text { Medium } \\
\text { High }\end{array}$ & $\begin{array}{r}7.9 \% \\
9.4 \% \\
34.2 \% \\
48.5 \% \\
\end{array}$ & $\begin{array}{r}7.1 \% \\
8.2 \% \\
31.6 \% \\
53.1 \% \\
\end{array}$ & $\begin{array}{r}8.5 \% \\
10.2 \% \\
31.9 \% \\
49.4 \% \\
\end{array}$ & $\begin{array}{l}15.0 \% \\
13.4 \% \\
31.1 \% \\
40.6 \%\end{array}$ & $\begin{array}{l}17.1 \% \\
15.3 \% \\
29.8 \% \\
37.8 \%\end{array}$ & $\begin{array}{r}7.1 \% \\
6.2 \% \\
29.4 \% \\
57.3 \% \\
\end{array}$ & $\begin{array}{r}10.0 \% \\
5.3 \% \\
29.9 \% \\
54.8 \% \\
\end{array}$ & $\begin{array}{r}7.3 \% \\
9.5 \% \\
36.2 \% \\
47.0 \% \\
\end{array}$ \\
\hline Home & $\begin{array}{l}\text { Missing } \\
\text { None } \\
1 \text { evening } \\
2 \text { evenings } \\
3 \text { evenings } \\
4 \text { evenings } \\
5 \text { evenings }\end{array}$ & $\begin{array}{r}10.2 \% \\
3.6 \% \\
14.1 \% \\
21.3 \% \\
26.8 \% \\
14.8 \% \\
19.3 \% \\
\end{array}$ & $\begin{array}{r}11.4 \% \\
4.2 \% \\
13.3 \% \\
17.6 \% \\
27.6 \% \\
14.8 \% \\
22.6 \% \\
\end{array}$ & $\begin{array}{r}4.0 \% \\
1.8 \% \\
7.8 \% \\
12.8 \% \\
26.9 \% \\
18.6 \% \\
32.2 \% \\
\end{array}$ & $\begin{array}{r}3.5 \% \\
2.2 \% \\
10.4 \% \\
17.9 \% \\
28.0 \% \\
15.7 \% \\
25.8 \%\end{array}$ & $\begin{array}{r}5.8 \% \\
2.1 \% \\
11.4 \% \\
19.7 \% \\
28.3 \% \\
14.8 \% \\
23.8 \%\end{array}$ & $\begin{array}{r}6.6 \% \\
4.3 \% \\
11.9 \% \\
17.3 \% \\
36.8 \% \\
10.6 \% \\
19.1 \% \\
\end{array}$ & $\begin{array}{r}3.7 \% \\
1.9 \% \\
6.0 \% \\
17.0 \% \\
30.1 \% \\
15.6 \% \\
29.4 \% \\
\end{array}$ & $\begin{array}{r}4.8 \% \\
2.1 \% \\
7.6 \% \\
18.0 \% \\
26.3 \% \\
19.3 \% \\
26.7 \%\end{array}$ \\
\hline $\begin{array}{l}\text { Academic self } \\
\text { concept }\end{array}$ & $\begin{array}{l}\text { Missing } \\
\text { Very high } \\
\text { High } \\
\text { Low } \\
\text { Very low }\end{array}$ & $\begin{array}{r}7.2 \% \\
18.3 \% \\
33.8 \% \\
33.9 \% \\
14.0 \% \\
\end{array}$ & $\begin{array}{r}8.9 \% \\
22.9 \% \\
34.6 \% \\
31.4 \% \\
11.2 \% \\
\end{array}$ & $\begin{array}{r}5.3 \% \\
30.9 \% \\
38.1 \% \\
24.1 \% \\
7.0 \% \\
\end{array}$ & $\begin{array}{r}6.7 \% \\
28.9 \% \\
41.6 \% \\
24.1 \% \\
5.4 \%\end{array}$ & $\begin{array}{r}9.1 \% \\
28.0 \% \\
38.0 \% \\
28.2 \% \\
5.9 \%\end{array}$ & $\begin{array}{r}8.0 \% \\
24.6 \% \\
31.5 \% \\
35.1 \% \\
8.8 \%\end{array}$ & $\begin{array}{r}7.5 \% \\
33.3 \% \\
36.5 \% \\
24.0 \% \\
6.2 \% \\
\end{array}$ & $\begin{array}{r}8.8 \% \\
25.3 \% \\
40.6 \% \\
25.2 \% \\
8.8 \%\end{array}$ \\
\hline $\begin{array}{l}\text { Attitude to } \\
\text { school }\end{array}$ & $\begin{array}{l}\text { Missing } \\
\text { Very high } \\
\text { High } \\
\text { Low } \\
\text { Very low }\end{array}$ & $\begin{array}{r}7.5 \% \\
26.7 \% \\
20.7 \% \\
26.1 \% \\
26.5 \%\end{array}$ & $\begin{array}{r}8.9 \% \\
26.7 \% \\
19.0 \% \\
30.2 \% \\
24.1 \%\end{array}$ & $\begin{array}{r}5.6 \% \\
42.5 \% \\
24.9 \% \\
23.4 \% \\
9.2 \%\end{array}$ & $\begin{array}{r}7.7 \% \\
44.1 \% \\
21.7 \% \\
23.9 \% \\
10.3 \%\end{array}$ & $\begin{array}{r}8.2 \% \\
38.2 \% \\
21.8 \% \\
27.3 \% \\
12.7 \%\end{array}$ & $\begin{array}{r}8.9 \% \\
30.2 \% \\
21.0 \% \\
25.6 \% \\
23.3 \% \\
\end{array}$ & $\begin{array}{r}7.5 \% \\
46.4 \% \\
16.8 \% \\
22.6 \% \\
14.2 \% \\
\end{array}$ & $\begin{array}{l}10.2 \% \\
34.3 \% \\
18.7 \% \\
29.3 \% \\
17.6 \%\end{array}$ \\
\hline $\begin{array}{l}\text { School \% } \\
\text { pupils FSM } \\
\text { band }\end{array}$ & $\begin{array}{l}\text { Missing } \\
35 \%+ \\
21 \%-35 \% \\
13 \%-21 \% \\
9 \%-13 \% \\
5 \%-9 \% \\
<5 \%\end{array}$ & $\begin{array}{r}1.3 \% \\
7.9 \% \\
13.0 \% \\
15.2 \% \\
15.6 \% \\
24.3 \% \\
22.7 \% \\
\end{array}$ & $\begin{array}{r}1.5 \% \\
19.5 \% \\
18.5 \% \\
17.5 \% \\
13.7 \% \\
15.5 \% \\
13.8 \% \\
\end{array}$ & $\begin{array}{r}.5 \% \\
22.8 \% \\
18.3 \% \\
25.5 \% \\
13.5 \% \\
7.9 \% \\
11.5 \% \\
\end{array}$ & $\begin{array}{r}.7 \% \\
51.7 \% \\
22.1 \% \\
9.3 \% \\
6.3 \% \\
5.3 \% \\
4.5 \% \\
\end{array}$ & $\begin{array}{r}1.6 \% \\
72.6 \% \\
9.9 \% \\
6.6 \% \\
4.2 \% \\
2.5 \% \\
2.5 \% \\
\end{array}$ & $\begin{array}{r}.9 \% \\
33.2 \% \\
27.7 \% \\
16.6 \% \\
9.3 \% \\
7.1 \% \\
5.1 \% \\
\end{array}$ & $\begin{array}{r}1.6 \% \\
45.9 \% \\
21.9 \% \\
11.7 \% \\
6.9 \% \\
6.6 \% \\
5.3 \% \\
\end{array}$ & $\begin{array}{r}1.4 \% \\
28.9 \% \\
16.1 \% \\
13.9 \% \\
13.9 \% \\
11.2 \% \\
14.6 \%\end{array}$ \\
\hline $\begin{array}{l}\text { School } \\
\text { admissions }\end{array}$ & $\begin{array}{l}\text { Secondary modern } \\
\text { Grammar } \\
\text { Comprehensive }\end{array}$ & $\begin{array}{r}4.9 \% \\
3.7 \% \\
91.3 \% \\
\end{array}$ & $\begin{array}{r}3.1 \% \\
4.2 \% \\
92.7 \% \\
\end{array}$ & $\begin{array}{r}2.2 \% \\
6.1 \% \\
91.7 \% \\
\end{array}$ & $\begin{array}{r}3.2 \% \\
1.8 \% \\
95.0 \%\end{array}$ & $\begin{array}{r}1.2 \% \\
.4 \% \\
98.4 \%\end{array}$ & $\begin{array}{r}1.3 \% \\
2.4 \% \\
96.4 \% \\
\end{array}$ & $\begin{array}{r}2.8 \% \\
2.5 \% \\
94.7 \% \\
\end{array}$ & $\begin{array}{r}4.6 \% \\
3.4 \% \\
92.0 \% \\
\end{array}$ \\
\hline school type & $\begin{array}{l}\text { Church } \\
\text { Foundation } \\
\text { Community }\end{array}$ & $\begin{array}{l}14.1 \% \\
17.0 \% \\
68.9 \% \\
\end{array}$ & $\begin{array}{l}17.3 \% \\
16.4 \% \\
66.3 \% \\
\end{array}$ & $\begin{array}{r}6.8 \% \\
17.1 \% \\
76.1 \% \\
\end{array}$ & $\begin{array}{r}2.9 \% \\
10.3 \% \\
86.7 \%\end{array}$ & $\begin{array}{r}9.7 \% \\
6.1 \% \\
84.1 \%\end{array}$ & $\begin{array}{l}24.3 \% \\
13.1 \% \\
62.6 \% \\
\end{array}$ & $\begin{array}{r}27.0 \% \\
8.5 \% \\
64.4 \% \\
\end{array}$ & $\begin{array}{l}17.1 \% \\
16.1 \% \\
66.7 \% \\
\end{array}$ \\
\hline School sex & $\begin{array}{l}\text { Boys school } \\
\text { Girls school } \\
\text { mixed }\end{array}$ & $\begin{array}{r}3.6 \% \\
3.6 \% \\
92.8 \% \\
\end{array}$ & $\begin{array}{r}5.5 \% \\
12.0 \% \\
82.5 \% \\
\end{array}$ & $\begin{array}{r}5.8 \% \\
10.3 \% \\
83.9 \% \\
\end{array}$ & $\begin{array}{r}4.0 \% \\
16.1 \% \\
79.9 \%\end{array}$ & $\begin{array}{r}8.7 \% \\
22.2 \% \\
69.1 \%\end{array}$ & $\begin{array}{r}6.9 \% \\
18.4 \% \\
74.6 \% \\
\end{array}$ & $\begin{array}{r}7.8 \% \\
16.9 \% \\
75.3 \% \\
\end{array}$ & $\begin{array}{r}7.6 \% \\
15.1 \% \\
77.2 \% \\
\end{array}$ \\
\hline IDACI & $\begin{array}{l}\text { most deprived } 25 \% \\
\text { middle } 50 \% \\
\text { least deprived } 25 \%\end{array}$ & $\begin{array}{l}25.1 \% \\
48.1 \% \\
26.7 \%\end{array}$ & $\begin{array}{l}45.6 \% \\
39.4 \% \\
14.9 \%\end{array}$ & $\begin{array}{l}34.3 \% \\
52.4 \% \\
13.2 \%\end{array}$ & $\begin{array}{r}66.3 \% \\
28.8 \% \\
4.9 \%\end{array}$ & $\begin{array}{r}85.9 \% \\
13.3 \% \\
.7 \%\end{array}$ & $\begin{array}{r}70.1 \% \\
26.8 \% \\
3.1 \% \\
\end{array}$ & $\begin{array}{r}70.6 \% \\
25.6 \% \\
3.7 \% \\
\end{array}$ & $\begin{array}{l}44.7 \% \\
38.0 \% \\
17.1 \%\end{array}$ \\
\hline
\end{tabular}

Note:

Where there are missing values for a variable the percentage of missing cases within each ethnic group is shown in the row titled 'Missing'. All other percentages are from a base of valid cases. The proportion of missing values is high for Pakistani and Bangladeshi groups on parent reported quarrelling, long term absence, SS/EWS service involvement, police involvement and exclusion because parents interviewed with the aid of an interpreter were not asked to complete the computer administered self-completion interview from which these variables were sourced. Percentages are weighted by design and nonresponse weights. 